\title{
Multi-level climate policies in Ireland
}

\author{
Jackie S. McGloughlin and Professor John Sweeney \\ Department of Geography, National University of Ireland Maynooth
}

\begin{abstract}
Global greenhouse gas concentrations continue to rise even though there are binding international agreements and national commitments for emission reductions. While some states and local governments around the world are taking action to reduce emissions and adapt to the inevitable climate change impacts, overall collective goals are not being realised and this implementation gap may be due to multi-level governance failures. To date there has been limited research of Irish climate measures with a significant gap at the subnational level. This research explores whether city and county councils are the lowest, most effective, level for climate change actions in Ireland through a nationwide survey and a review of all relevant government policies at local, regional and national levels. This research reveals that the local climate measures are isolated best practice examples rather than being widespread throughout the country. This study concludes that there is limited vertical integration among Irish government levels as evidenced by three things: survey responses from local authority staff members, limited incorporation of higher-level objectives into local policy documents, and limited details in national level policies as to local level implementation. Similar to municipalities in other countries, Irish local authorities face challenges which are hindering their advancement of climate measures. If the higher-level collective goals are to be achieved in Ireland, the national government will need to drive forward the climate change agenda with formalised commitments and mandatory local implementation.
\end{abstract}

Keywords: climate change, local governance, subsidiarity, environmental policy

\section{Introduction}

Despite international agreements to prevent dangerous anthropogenic interference with the climate system, global greenhouse gas concentrations continue to rise and "warming of the climate system is unequivocal" (IPCC 2007, 30). Both the United Nations Framework Convention on Climate Change (UNFCCC) and the Kyoto Protocol have been transposed into European Union (EU) policies as part of an increasing focus on environmental issues(Jordan 2000; CEC 2009). Even with these strategic objectives, the greenhouse gas (GHG) emissions for the collective EU-15 still exceed the Kyoto Protocol target. This is not surprising since ten of the EU-15 member states have GHG emissions higher than their negotiated targets (EEA 2009a). Further, there is a wide range of success and failure by member states when considering the period from 1990 to 2007. The greatest success is Latvia's 55 per cent decrease in emissions, but the least promising result is Turkey's 119 per cent increase in emissions for the same period (EEA 2009a). With regard to adaptation, most member states have no formal national adaptation policies, and only eleven member states have published strategies. The remaining twenty-one EU member states, including Ireland, 
have no formalised national adaptation strategy (EEA 2009b). Overall, climate change is a pressing issue, but current actions are not sufficient to address climate change fully.

A comprehensive approach addressing climate change should extend through all levels of government including actors at the municipal level (Wilbanks 2007; Adger 2005). While the state is the key player within the EU administrative framework (Aalberts 2004), there are also expanding roles for sub-national actors. Ideally, integrated vertical policies merge higher-level policy objectives with 'on-the-ground' implementation. The nested hierarchy of government requires that national governments oversee holistic policies, and local governments implement policies within their spatial area (Hooghe and Marks 2003). More generally, the scale of policy design and implementation has been an underlying theme in EU policy analyses (MacLeod 1999) and in climate change literature (Sovacool and Brown 2009). The subsidiarity principle in the Maastricht Treaty supports actions taken at the lowest, most appropriate, level (Minoia et al. 2009). This applies to climate change in that individuals and local businesses take the actions to reduce greenhouse gas emissions. However, higher-level policy objectives may, or may not, be implemented at the local level (Urwin and Jordan 2008; Wilson 2006). Therefore, the subsidiarity principle has relevance for policy design and implementation between the supranational EU and nation states; and this principle has relevance for nation states and their sub-national government levels (Collier 1997).

The scope in Ireland for vertical integration is limited to central and local government relations because there is no meaningful regional tier of government. In Ireland, the subnational government levels and vertical integration have been affected by EU funding and regulations. Extensive EU funding provided for the creation of a regional tier of government and eight new regional authorities established in 1994 (Philip 1994). This regional tier of government is intended to balance a strategic focus with local variations through Regional Strategic Planning Guidelines. While many European countries have meaningful regional tier authorities, this was largely lacking in Ireland (Quinn 2003). "To date, regional authorities have had relatively little power. With a tiny staff contingent and no budget, their main role has been to monitor the ways in which Structural Funds have been spent" (Boyle 2000:742). This contrasts starkly with the potential benefit of regional authorities to provide an expertise base for local authorities. If these meaningful conglomerations are lacking, each local authority potentially needs to have extensive climate change knowledge and expertise (Huang 1997). 
Institutional issues such as funding, staffing, technical expertise, and administrative structures limit local climate measures (Tribbia and Moser 2008). In practice, converting laudable environmental goals to action is complicated (Betsill and Bulkeley 2006). Implementation gaps occur when responsibilities are devolved to local authorities without designated resources (Lundqvist and von Borgstede 2008; Betsill and Bulkeley 2004; Lankao 2007). This may present challenges for Irish local authorities since there is no designated funding to address climate change (Davies 2005).

National governments have a defining role for local authorities' policies. Central government initiatives jumpstart locally based policies (Aall et al. 2007, Urwin and Jordan 2008) and national policies dictate many local authority actions (Bulkeley and Betsill 2003; Næss et al. 2005). Additionally, local governments sometimes have the political will to advance climate policies, but they lack the financial resources to do so. For example, limited finances hindered adaptations in three sub-national governments in Japan, Germany and Brazil (Puppim de Oliveira 2009). In each of these cases, inadequate financing resulted in a greater focus on mitigation than adaptation. Local authority's capacity to address climate change is questionable; however, some local authorities have taken action even while experiencing these barriers. Local governments are affected by higher-level frameworks (Adger et al. 2005; Betsill and Bulkeley 2004; Cash and Moser 2000). These higher-level frameworks play out very differently among local authorities in the same nation state. Adaptation is also limited when local authorities lack a sense of agency and claim they have little responsibility for key areas of mitigation and adaptation policies (Demeritt and Langdon 2004; Wilson 2006a).

In countries around the world, most local actions are mitigation with a lesser focus on adaptation (Bulkeley and Betsill 2003; Allman et al. 2004; Wilson 2006; Tribbia and Moser 2008). For example, the Australian government is using local renewable energy schemes in Newcastle as demonstration projects (Betsill and Bulkeley 2006). Local adaptation measures in place are only assessing options and planning for future actions (Perkins et al. 2007) and are unlikely to advance before tangible impacts occur (Wilbanks 2007, Shackley and Deanwood 2002, Amundsen et al. 2010). Even with these tangible impacts, current policy frameworks limit options that can be adopted (Shackley and Deanwood 2002). This implementation deficit exists despite supranational agreements and increased available information: transformation from aspirations to implementation is not widespread. In 
summary, most local authorities are not prepared to deal with current climate vulnerability or increasing vulnerability with anticipated climate change (Allman et al. 2004; Lankao 2007).

Considering these difficulties, this paper aims to review current sub-national climate measures in Ireland and to highlight best practice examples. Key issues regarding subnational variations in climate policy and the need for vertical integration are explored with a view towards drawing similarities between the Irish example and other international experiences. The authors acknowledge that international context varies for local government autonomy and the aim of this paper is to contribute to the discourse through a case study approach of Ireland. The paper concludes with considerations of wider issues regarding scale of climate policies and the relevance of subsidiarity.

\section{Methodology}

This case study includes a survey of city and county local planning offices as well as a document review of all city and county development plans. Town and borough councils were not included in this case study as most planning applications are processed at the city and county council level. Overall, the fifteen question survey focuses on local planners' perceptions about climate change impacts and related municipal responses. Most of the fifteen questions involved short answers and ticking boxes, and respondents were given the opportunity to supplement their answers with additional information. Survey participants were assured of confidentiality and all results are presented in aggregated form. All thirtyfour City and County Council planning offices were contacted by telephone to identify the person in the planning department who was familiar with the current development plan and related climate change issues. The questionnaire was disseminated by email and post during the summer of 2009 with follow-up contacts during the autumn. Completed questionnaires were obtained from 31 planning offices representing a response rate of 91 per cent which provides a good representation of local authority opinions and knowledge.

The local perspectives were compared with formal policies through a document review of all city/county development plans and relevant national policies. The final versions of all policies in effect through July 2010 were used for this study; draft plans were not considered since they are not in force and may be subject to changes before being formally adopted. The city and county development plans were reviewed for measures relating to climate change, based on the following criteria: 1) explicit links with climate change impacts, 2) explicit links with greenhouse gas reductions, or 3) added measures beyond those required 
by national policies. Survey responses and relevant development plan measures were analysed using SPSS software. Non-parametric correlations were determined by Kendall's tau b (two-tailed tests) to avoid 'ties' in the data given that many local authorities had similar number of proactive measures and presence/absence of a climate change strategy is a categorical value. A p value of $<0.05$ was considered statistically significant for the analysis. This analysis was used to assess local governmental innovations throughout Ireland and served as a starting point to assess relative proactive measures.

\section{Results}

Although local authorities anticipate that climate change will affect their locality (Table 1Fable 1), and some climate change actions have been taken at all levels of government (national, regional and local), these measures have been adopted in an ad hoc manner with some sectors receiving more attention than others. This non-standardised approach has negatively affected Irish preparedness for climate change and is confounded by barriers and limitations at the local level.

Table 1 Survey responses of anticipated impacts due to projected climate change by 2050

\begin{tabular}{|l|c|c|c|c|}
\hline & $\begin{array}{c}\text { High } \\
\text { impact }\end{array}$ & $\begin{array}{c}\text { Limited } \\
\text { impact }\end{array}$ & $\begin{array}{c}\text { No anticipated } \\
\text { impact }\end{array}$ & No answer \\
\hline Flooding & $61 \%$ & $26 \%$ & $0 \%$ & $13 \%$ \\
\hline Water Supply & $42 \%$ & $35 \%$ & $6 \%$ & $16 \%$ \\
\hline Biodiversity & $39 \%$ & $48 \%$ & $0 \%$ & $13 \%$ \\
\hline Coastal erosion/sea level rise) & $48 \%$ & $16 \%$ & $26 \%$ & $10 \%$ \\
\hline Landslides & $13 \%$ & $52 \%$ & $26 \%$ & $10 \%$ \\
\hline Agriculture & $19 \%$ & $55 \%$ & $13 \%$ & $13 \%$ \\
\hline Temperature & $10 \%$ & $71 \%$ & $0 \%$ & $19 \%$ \\
\hline Other & $10 \%$ & $6 \%$ & $0 \%$ & $84 \%$ \\
\hline
\end{tabular}

While Irish local authorities have not prepared for climate change, they do anticipate that climate change will impact their local area as shown in the above Table 1 . These impacts were mostly commonly cited as high impact for flooding, water supply, coastal erosion and biodiversity. Flooding is a key area of concern for local authorities as the first responders and the profile of climate change and flooding has been raised through the work of the Office of Public Works and their work with local authorities preparing Catchment Flood Risk Assessment and Management Studies. Coastal issues are also a great concern for local authorities since most Irish cities and counties are on the coast. Those local authorities who indicated 'no anticipated impact' are all inland counties without any coastline. Conversely, there was much less resonance for landslides, agriculture and higher temperatures. Ireland is not a high risk area for landslides; however, these may increase with projected climate 
change (Creighton 2006; Dykes et al. 2008) and have affected water supplies as recently as 2008 (Lucey 2008). Notwithstanding, few local authorities anticipate high impacts related to landslides and climate change. Agriculture does not fall under the remit of local authorities; rather this sector is administered by central government with individual farmers through EU policies. Temperature changes are a much less concrete impact and would not have designated departments assigned to address this. Overall, climate change is expected to impact local areas, and this will impact local authorities' service provisions.

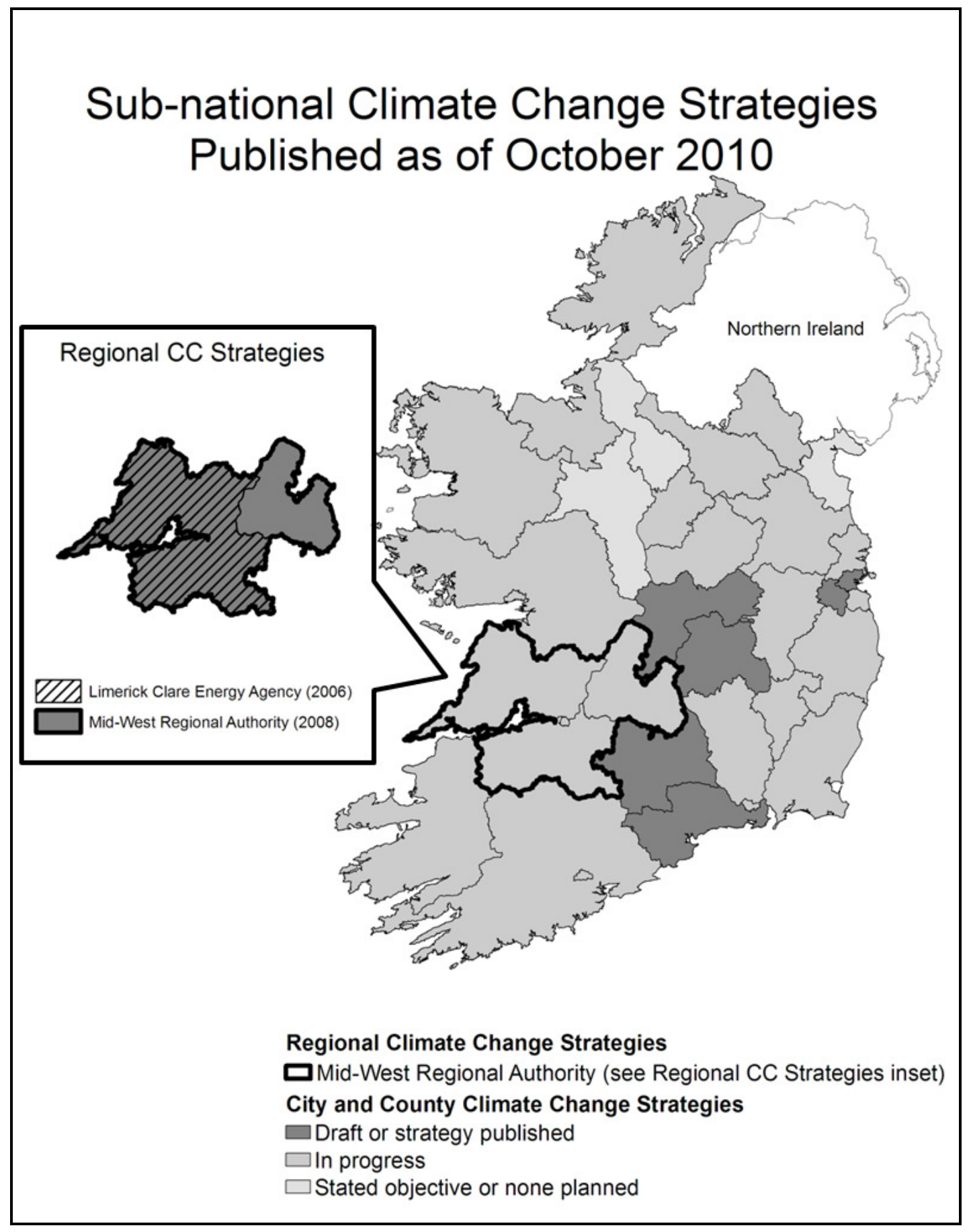

Figure 1 Sub-national climate change strategies 
As Figure 1 depicts, six leading local authorities have already published their climate change strategies in draft or final form, and twenty-two other city and county councils are "working with their local energy agencies to implement climate change strategies at local level" (Association of Irish Energy Agencies, accessed 16/4/10). While energy agencies provide advice and guidance to local authorities in addressing climate change, this has not resulted in a published strategy for most Irish local authorities. Population density is another factor which is not statistically significant in whether a local authority has a published strategy $(\tau=-.148$, significant at .289$)$. From a more physical exposure consideration, local authority survey responses for anticipated high impacts did not correlate with having a published climate change strategy $(\tau=.161$, significant at .312$)$. Finally, the above map shows that the six leading authorities are clustered geographically, and the regional climate change strategy involves three spatially contiguous authorities. Limerick County Council, the Limerick City Council, and Clare County Council took a different route to preparing their local climate change strategies. Rather than preparing individual strategies, these county councils, working together with the Limerick Clare Energy Agency (LCEA), published a joint strategy in June 2006. This initial strategy was expanded to include North Tipperary County Council in June 2007 with the publication of the Mid-West Energy Balance \& Climate Change Strategy (Figure 1 inset). These regional strategies include quantified emissions and explicit county level $\mathrm{CO}_{2}$ targets referencing the Kyoto Protocol. This approach was also taken by Waterford County Council; their 2008 strategy includes detailed 2005-2007 $\mathrm{CO}_{2}$ sectoral emissions and specific possible actions listed by Directorate, a qualitative assessment of $\mathrm{CO}_{2}$ savings, and practical implementation considerations such as HR problems, public/political problems, and ease of implementation (WCC 2008). Similarly, Dublin City Council includes sectoral non-quantified targets in its strategy and expands this in their follow-up 2009 First Year Strategy to include quantified results of indicators. Conversely, draft climate change strategies without quantified emissions or targets have been adopted by Laois County Council and Offaly County Council. These examples represent the climate leaders in Ireland since there are no published strategies for the other twenty-six city and county councils.

For both the county and regional climate change strategies, there is a primary focus on energy issues rather than a more holistic approach to both climate mitigation and adaptation. Energy efficiency measures are the key focus of many local authority climate change actions. Most of the 430+ initiatives included in the 2008 County and City Managers' Association 
(CCMA) report are internal local authority measures related to energy efficiency and renewable energy. According to the CCMA, local authorities are also preparing energy audits, raising internal awareness, and reducing waste through internal staff procedures. The CCMA advocates that local authorities establish a cross-departmental team with management buy-in, and this representative body has established a Climate Change Working Group to advise the general body regarding climate change issues and includes members from city and county councils; energy agencies; Department of the Environment, Heritage, and Local Government; and Office for Local Authority Management (CCMA 2008). A similar crosssectoral approach is being employed by nine local authorities who have established internal working groups for climate change or energy. Generally, however, there is a no standardised approach at city and county level with regard to climate change (CCMA 2008).

Figure 2 below shows that development plans vary in their number and type of climate related proactive measures: some plans link as many as six sectors with climate change while others have few or none. All the councils have addressed their statutory requirements and this map depicts those measures going beyond this minimal requirement, i.e. added proactive measures directly addressing climate change. For example, Dublin City Council includes a full chapter on climate change with scenarios and specific impacts that will need to be addressed. Conversely, Laois County Council includes no measures or assessments of impact, but merely includes a reference that " $\mathrm{CO}_{2}$, a greenhouse gas, may cause climate change" (LCC 2006: 76). These plans were all adopted between 2004 and 2010 with no significant increase in climate related measures during the period $(\tau=.089$, significant at .516). It is also remarkable that adjacent authorities have different climate change measures that are not uniformly adopted by city and county local authorities. For example, Waterford City Council addresses energy, flooding and transportation, whereas Waterford County Council only addresses flooding and transportation. Overall, there are limited additional measures beyond generalised references to higher level policies as required by central government. When considering the country as a whole, energy considerations were the most commonly addressed issues followed closely by flooding and transport. These issues relate to short term gains and long term strategies issues affecting the locality. 


\section{Development Plan Review}

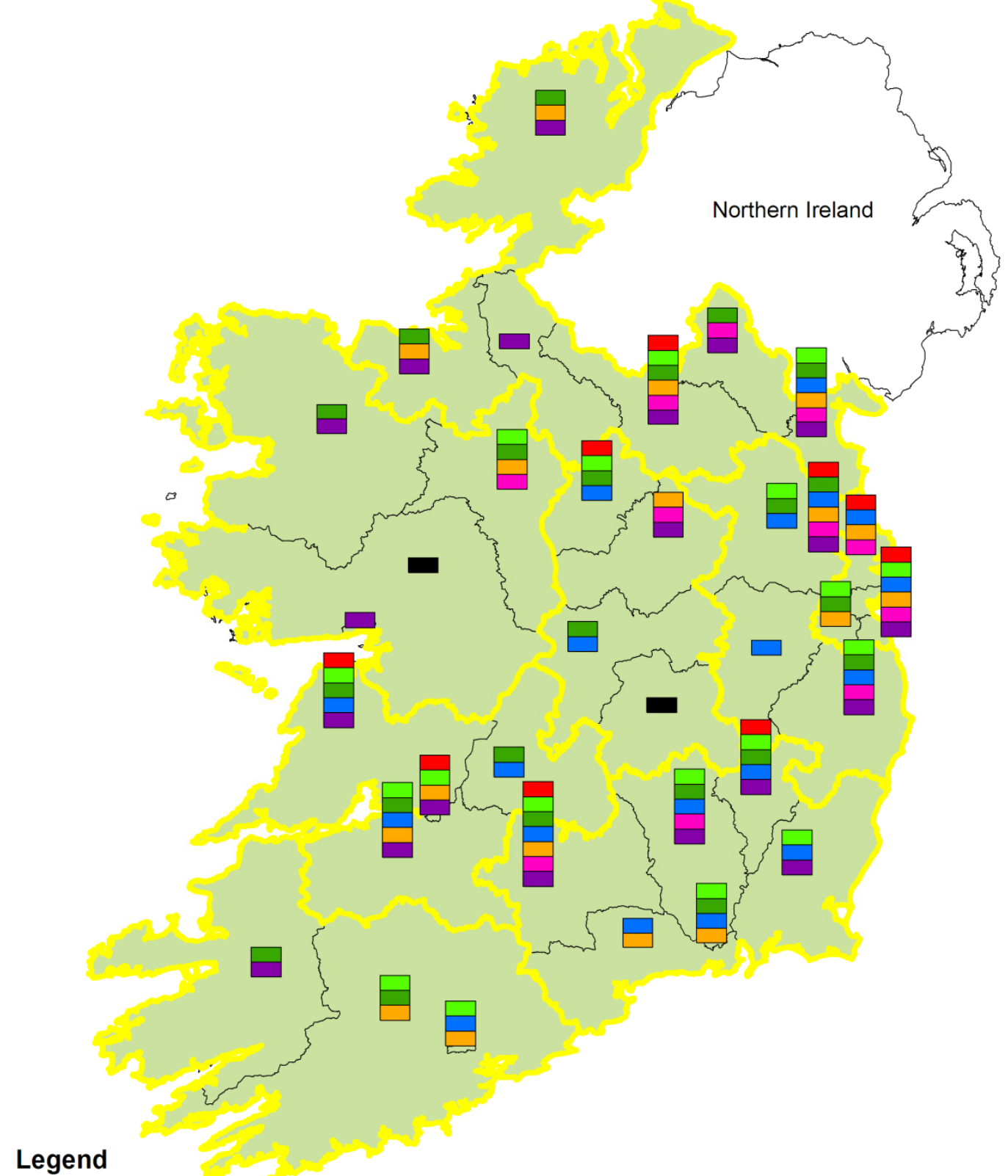

\section{Legend}

Regional Authorities

City/County Local Authorities

Development Plans in effect as of June 2010.

\begin{tabular}{|c|c|c|c|c|c|c|c|c|}
\hline & Climate & $\begin{array}{c}\text { Energy - } \\
\text { Demand } \\
\text { Reduction }\end{array}$ & $\begin{array}{c}\text { Energy - } \\
\text { Renewables }\end{array}$ & Flooding & Transport & $\begin{array}{c}\text { Residential } \\
\text { Density }\end{array}$ & Other* & $\begin{array}{c}\text { No measures } \\
\text { in plan }\end{array}$ \\
\cline { 2 - 9 } & & & & & & & & 21 \\
\hline
\end{tabular}

Figure 2 Added measures included in city and county development plans

Long-term strategic measures are varied in their quantity and type of issues and this was confirmed by survey respondents. Local authorities were asked how strategic issues were 
addressed in the development plans, insofar as some issues extend beyond the six year development plan renewal period. Results from the responses (two survey participants did not answer this question and they are omitted from this part of the analysis) were coded by sectoral categories and are presented to illustrate the wide range of quantity and types of issues referenced below in Figure 3. These variations in these responses echo the results from the development plan review in that local approaches are not standardized in Ireland.

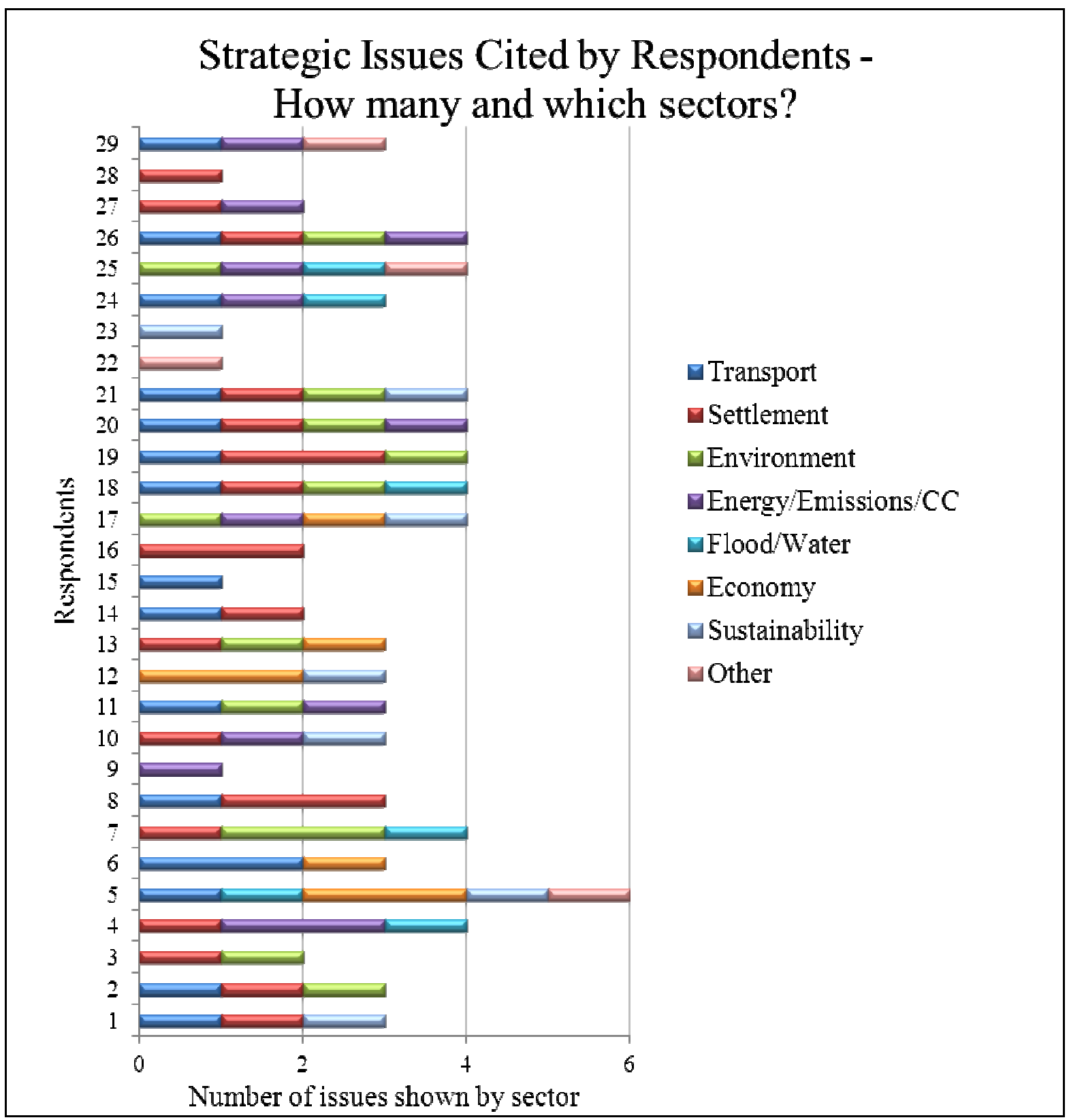

Figure 3 Strategic issues cited by respondents. This graph shows the strategic issues, represented by coloured segments, cited as important by each county. The variety in number and colour of segments illustrates the non-standardised approach to long-term strategic issues at the local level. 
All Irish local authorities are required to have regard for the same EU and national guidelines; however, the respondents' lists of higher level policies with synergies for climate change and local development plans varied widely in the specific policies referenced as well as quantity of policies referenced. With regard to quantity of policies referenced, survey respondents $(n=27)$ cited few higher level policies $(\mu=8.52)$. Some respondents answering this question included an extensive list [ 44 policies by R19 and 30 policies by R21] that would have synergies with climate change, while others listed as few as one (R4 and R31) or two (R10, R12, and R14). Table 2 below reports the wide variety of policies cited by respondents covering a range of spatial planning, sustainable development and environmental policies. Interestingly, only half of the respondents (16 of 31) include the National Climate Change Strategy in their list of relevant policies. Additionally, very few (4 of 31) cited the National Spatial Strategy as relevant to having synergies between planning and climate change. Conversely, from a top-down perspective, clear synergies between these two policy concerns are included in the National Climate Change Strategy. The wide variance of responses from local authorities, operating under the same legislative framework, is evidence that national level policies are not translated to local development plans and indicates a lack of vertical integration regarding climate related policies.

Table 2 Higher level policies with synergies between climate change and development plans

\begin{tabular}{|l|c|l|c|}
\hline National Policies and Regulations & $\begin{array}{c}\# \\
\text { Citing } \\
\text { Policy }\end{array}$ & Supra-national Policies & $\begin{array}{c}\# \\
\text { Citing } \\
\text { Policy }\end{array}$ \\
\hline Planning Regulations & 26 & Water Framework & 16 \\
Biodiversity/Wildlife/Heritage & 17 & Wildlife Conventions & 16 \\
National Climate Change Strategy & 16 & Habitats Directive & 12 \\
Energy & 11 & Strategic Environmental Assessment & 12 \\
Sustainable Development & 10 & Wild Birds Directive & 8 \\
National Flood Guidelines & 9 & Floods Directive & 7 \\
Planning/Development Act & 8 & Social Partnership & 7 \\
National Development Plan & 5 & Groundwater/Drinking/Bathing & 6 \\
Waste Management & 5 & EU Transport Policy & 5 \\
National Spatial Strategy & 4 & Urban Waste-Water & 4 \\
Transport 21 & 4 & UNESCO/EU Heritage & 3 \\
Forestry Act & 1 & Environmental Impact Assessment & 3 \\
Extractive Industries & 1 & Spatial/Rural Development & 3 \\
& & Kyoto Protocol & 2 \\
& & EU Climate Change & 2 \\
& & EU Energy Buildings & 2 \\
\hline & & Waste/Pollution & 1 \\
\hline
\end{tabular}


There was more widespread agreement about the scale of policy implementation. Most respondents set forth responsibility at either the local or central government level (Figure 4) which reflects the lack of policy implementation at regional scale in Ireland. The mid-level authorities such as river basin management associations, waste management groupings and regional authorities are not reflected in the survey responses with responsibilities most often split between local and central government. Granted some respondents viewed this responsibility differently; they indicated that responsibility was shared between local and central government, and five of these perceived shared responsibility for three or more sectors. This suggests a different conceptualisation of the division of responsibilities and may represent a partial deflection of responsibility or may acknowledge the limitations of local responses. The policy agenda set at national level, that local authorities have a role to play in climate change, is not being realised with regard to local climate change strategies and mainstreaming climate change into local policies such as the development plans.

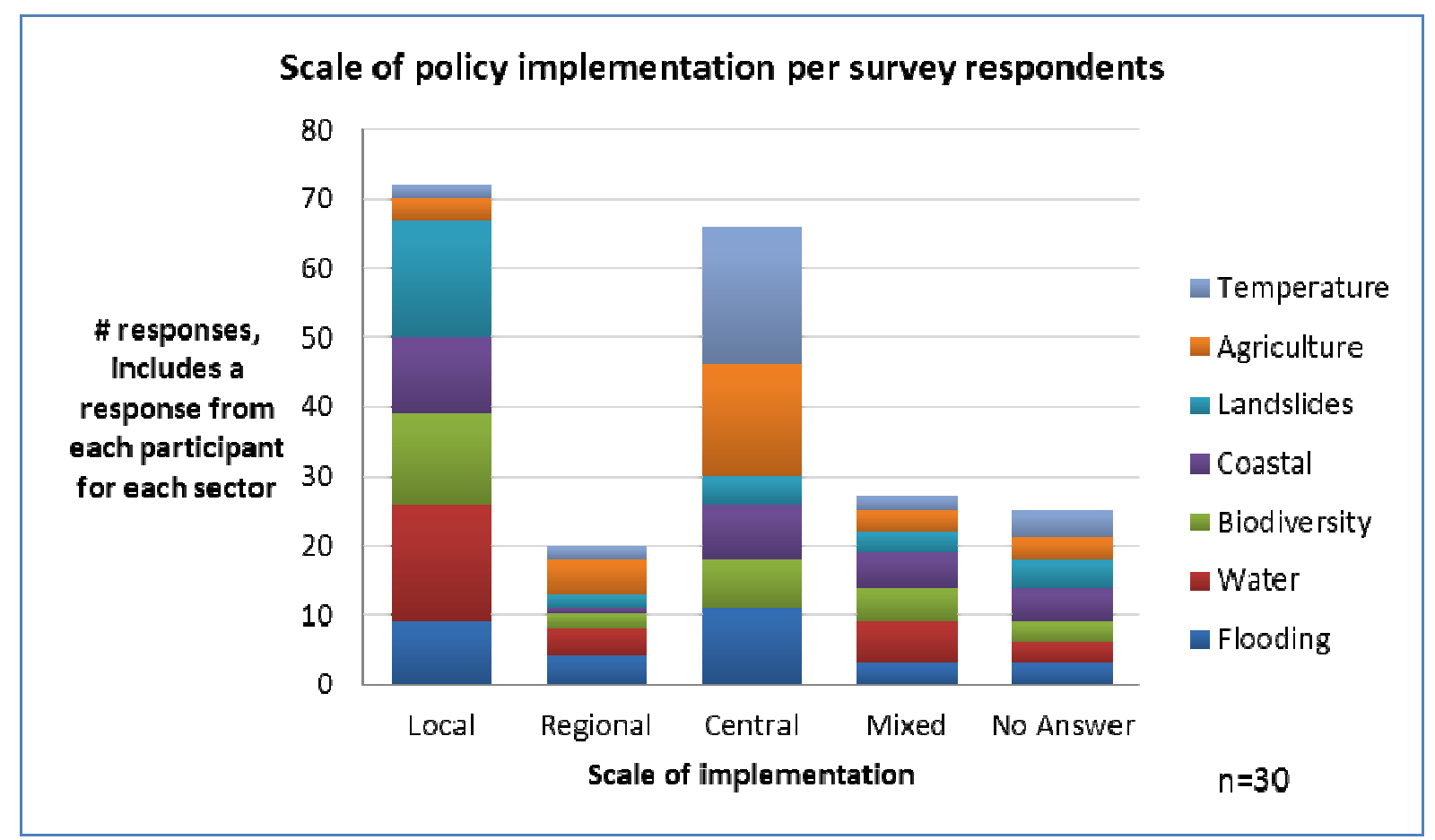

Figure 4 Scale of policy implementation as per survey respondents

Similar to experiences in other countries, most Irish local authorities identify many challenges which may hinder their local climate measures. Each city and county council was asked about difficulties which would affect their efforts to address climate change, both currently and those anticipated in the future (Table 3). A review of the most commonly cited 
barriers, supplemented by consideration of types of barriers, allows insights into limiting factors for proactive climate measures

Table 3. Barriers to local authorities addressing climate change

\begin{tabular}{|l|c|c|}
\hline & Currently & $\begin{array}{c}\text { Anticipated } \\
\text { in Future }\end{array}$ \\
\hline Lack of funding & $77 \%$ & $61 \%$ \\
\hline Other issues take higher priority in the authority & $77 \%$ & $32 \%$ \\
\hline No nominated champion to drive it forward & $71 \%$ & $26 \%$ \\
\hline Lack of awareness or interest from councillors & $71 \%$ & $13 \%$ \\
\hline Lack of awareness or interest from the public & $68 \%$ & $16 \%$ \\
\hline Insufficient staff/staff time & $65 \%$ & $48 \%$ \\
\hline Lack of specialist knowledge in council & $65 \%$ & $32 \%$ \\
\hline Coordination difficulties regionally between areas & $65 \%$ & $32 \%$ \\
\hline Coordination difficulties among different departments within authority & $65 \%$ & $23 \%$ \\
\hline Lack of appropriate central government guidance & $65 \%$ & $10 \%$ \\
\hline Lack of appropriate central government regulations & $61 \%$ & $10 \%$ \\
\hline Perceived lack of priority or leadership from central government & $58 \%$ & $10 \%$ \\
\hline Difficulty embedding climate change action in other plans and strategies & $55 \%$ & $19 \%$ \\
\hline Insufficient local authority powers & $48 \%$ & $32 \%$ \\
\hline Risk of litigation (planning appeals etc.) & $39 \%$ & $26 \%$ \\
\hline Coordination difficulties between county and regional councils & $39 \%$ & $19 \%$ \\
\hline Lack of awareness or interest from other public sector organisations & $39 \%$ & $13 \%$ \\
\hline Lack of awareness or interest from staff & $39 \%$ & $3 \%$ \\
\hline Coordination difficulties between county and town councils & $29 \%$ & $10 \%$ \\
\hline
\end{tabular}

Most local authorities (77 per cent) acknowledge funding as a current barrier to addressing climate change and almost as many (61 per cent) anticipate this barrier to continue in the future. The lack of funds for climate measures reported by local authorities herein concurs with the issue among Irish energy agencies as reported by Davies (2005). However, even with funding barriers, proactive climate measures are still possible. For example, survey respondent \#2 noted that "energy efficiency mitigates against issues about lack of funding." Therefore, dedicated funding will help advance climate measures, but is not a determining factor to initial proactive climate measures at the local level.

Currently, most local authority staff members acknowledge barriers to addressing climate change, but fewer of these respondents anticipate these barriers in the future. Thirteen of the nineteen listed barriers were cited currently by more than half of the survey respondents. On the other hand, less than one-third of respondents cited any barriers, other than funding or staffing, as continuing in the future. This shift in expectations suggests an anticipated improvement in central government drivers and public support. 
With regard to staff resources as a barrier to implementing climate measures, it might be expected that added forward planning staff would correspond with more proactive measures for any given local authority. However in the Irish case, the number of 2008 forward planning staff numbers did not correlate with the number of additional proactive measures in current development plans as of July $2010(\tau=.143$, significant at .264). Therefore, while staffing issues were commonly cited, the analysis suggests that staffing numbers are not a determining factor towards proactive climate measures.

\section{Conclusions}

Ireland has not mainstreamed climate change considerations into planning policies and this can be explained in part by the weak links between government tiers and lack of strong drivers from central government. There is no statutory requirement for local authorities to mainstream climate change and no formal climate-related responsibilities designated for regional authorities. Given the lack of statutory requirements and designated responsibilities, best practice examples are unlikely to be adopted on a widespread scale to reduce greenhouse gas emissions or to adopt proactive climate adaptation measures. The progress of local authorities towards preparing their climate change strategies are only the beginnings of climate change actions and there is still a long path to travel. The fragmented sectoral approach to government presents key policy challenges since climate change impacts are cross-sectoral and are best served with integrated approaches. Therefore, in order to expand initial measures, links within authorities (horizontal) and between different government levels (vertical) need to be improved (Koch et al. 2007; Betsill and Bulkeley 2006).

Climate change policies encompass mitigation and adaptation; and projected climate change impacts will require coordinated planned adaptation. The central government policies have started to address climate change issues, and central government regulations and funding dictate the current role for local authorities in Ireland. To date, successful implementation is still pending and integrated responses are yet to be coordinated between different government levels. National climate policies are not realising enough emission reductions to meet EU targets and are only beginning to address climate adaptation. This environmental policy issue highlights the EU's uneasy balancing act between realising collective policy goals and respecting its member states' sovereignty: prescriptive policies have fallen short of practical implementation. 
Given the limited success of climate policies, this raises the question again of subsidiarity within the EU and its member states. If the subsidiarity principle sets forth that actions should be taken at the lowest effective level of government, are the city and county councils the most effective level for climate policy design? Within the Irish context, the evidence from this research suggests that city and county council level is not the most effective. Rather, national government will need to formalise their commitment to meaningful climate measures if Ireland is to fully address climate change.

\section{Acknowledgements}

This article is written within the framework of the CoCoAdapt project 2007-CCRP2.2.6 and supported by the Environment Protection Agency (EPA) as part of the STRIVE programme 2007-2013. Thanks go to the local authority staff members for their cooperation and input into this research. The authors also wish to thank Professor Mark Boyle, Ronan Foley, and two anonymous reviewers for their comments on the draft of this article.

\section{References}

Aalberts, T.E., 2004. The future of sovereignty in multilevel governance Europe - a constructivist reading. Journal of Common Market Studies, 42 (1), 23-46.

Aall, C., Groven, K. and Lindseth, G., 2007. The scope of action for local climate policy: the case for Norway. Global Environmental Politics, 7 (2), 83-101.

Adger, W.N., Arnell, N.W. and Tompkins, E.L., 2005. Successful adaptation to climate change across scale. Global Environmental Change, 15 (2), 77-86.

Allman, L., Fleming, P. and Wallace, A., 2004. The progress of English and Welsh local authorities in addressing climate change. Local Environment, 9 (3), 271-293.

Amundsen, H., Berglund, F. and Westskog, H., 2010. Overcoming barriers to climate change adaptation - a question of multilevel governance? Environment and Planning $C$ : Government and Policy 28 (2), 276-289.

Association of Irish Energy Agencies (AIEA), 2010. AIEA and Local Authorities Climate Change Strategies, http://www.aiea.ie/aiea_local_authorities/aiea_local_authorities_climate_change_str ategies, accessed 16/4/2010.

Betsill, M. and Bulkeley, H., 2004. Transnational networks and global environmental governance: the Cities for Climate Protection Program. International Studies Quarterly, 48 (2), 471-493.

Betsill, M.M. and Bulkeley, H., 2006. Cities and multilevel governance of global climate change. Global Governance, 12 (2), 141-159.

Boyle, M., 2000. Euro-regionalism and struggles over scales of governance: the politics of Ireland's regionalization approach to Structural Fund allocations 2000-2006. Political Geography, 19 (6), 737-769. 
Bulkeley, H. and Betsill, M.M., 2003. Cities and Climate Change: Urban Sustainability and Global Environmental Governance. New York: Routledge.

Cash and Moser, 2000. Linking global and local scales: designing dynamic assessment and management processes. Global Environmental Change 10 (2), 109-120.

CCMA: County \& City Managers' Association, 2008. Local authority climate change and energy efficiency measures: best practice and current initiatives. Dublin, CCMA.

Commission of the European Communities (CEC), 2007. Limiting global climate change to 2 degrees Celsius: the way ahead for 2020 and beyond. Brussels, CEC.

Collier, U., 1997. The EU and climate change policy: the struggle over policy competences, in Collier, U. and Löfstedt, R.E. (eds.) Cases in Climate Change Policy: Political Reality in the European Union, London, Earthscan Publications Limited, 43-64.

Creighton, R. (2006) Introduction In: Creighton, R., ed. (2006) Landslides in Ireland: a report of the Irish Landslides Working Group. Dublin, Geological Survey of Ireland. Ch. 1.

Davies, A.R., 2005. Local action for climate change: transnational networks and the Irish experience. Local Environment, 10 (1), 21-40.

Demeritt, D. and Langdon, D., 2004. The UK climate change programme and communication with local authorities. Global Environmental Change, 14 (4), 325-336.

Dublin City Council, 2005. Greater Dublin Strategic Drainage Study: Regional Drainage Policies, Technical Document, Volume Five, Climate Change. Dublin, DCC.

Dykes, A.P., Gunn, J. and Convery (Née Kirk), K.J., 2008. Landslides in blanket peat on Cuilcagh Mountain, northwest Ireland. Geomorphology, 102 (3-4), 325-340.

European Environment Agency (EEA), 2009a. Greenhouse gas emission trends and projections in Europe 2009: tracking progress towards Kyoto targets. EEA Report No. 9/2009. Copenhagen, EEA.

European Environment Agency (EEA), 2009b. Progress towards national adaptation strategies [online]. Available at: http://www.eea.europa.eu/themes/climate/nationaladaptation-strategies (accessed 3 November 2010).

Hooghe, L. and Marks, G., 2003. Unraveling the central state, but how? Types of multi-level governance. American Political Science Review 97 (2), 233-243.

Huang, J.C.K., 1997. Climate change and integrated coastal management: a challenge for small island nations. Ocean \& Coastal Management, 37 (1), 95-107.

IPCC, 2007. Climate Change 2007: Synthesis Report. Contribution of Working Groups I, II and III to the Fourth Assessment Report of the Intergovernmental Panel on Climate Change [Core Writing Team, Pachauri, R.K. and Reisinger, A. (eds.)]. Geneva, Switzerland, IPCC, 104 pp.

Jordan, A., 2000. The politics of multilevel environmental governance: subsidiarity and environmental policy in the European Union. Environment and Planning A 32 (7), $1307-1324$

Koch, I.C., Vogel, C. and Patel, Z., 2007. Institutional dynamics and climate change adaptation in South Africa. Mitigation and Adaptation Strategies for Global Change $12(8), 1323-1339$. 
Lankao, P., 2007. How do local governments in Mexico City manage global warming? Local Environment, 12 (5), 519-535.

Laois County Council, 2006. Laois County Development Plan 2006-2012. Portlaoise, LCC.

Limerick Clare Energy Agency, 2006. Limerick Clare Climate Change Strategy. Limerick, LCEA.

Lucey, A., 2008. Landslide cuts water supplies to 30,000 in north Kerry. Irish Times, [online], 25 August $2008 . \quad$ Available at: http://www.irishtimes.com/newspaper/ireland/2008/0825/1219449685613_pf.html (accessed 30 March 2009).

Lundqvist, L.L. and von Borgstede, C., 2008. Whose responsibility? Swedish local decision makers and the scale of climate change abatement. Urban Affairs Review, 43 (3), 299324.

MacLeod, G., 1999. Place, politics and 'scale dependence': exploring the structuration of the Euro-regionalism. European Urban and Regional Studies, 6 (3), 231-253.

Minoia, P., Calzavara, A., Lovo, L. and Zanetto, G., 2009. An assessment of the principle of subsidiarity in urban planning to face climate change. International Journal of Climate Change Strategies and Management 1 (1), 63-74.

Næss, L. O., Bang, G., Eriksen, S. and Vevatne, J., 2005. Institutional adaptation to climate change: flood responses at the municipal level in Norway. Global Environmental Change 15 (2), 125-138.

Perkins, B., Ojima, D. and Corell, R., 2007. A Survey of Climate Adaptation Planning. Washington, The Heinz Center.

Philip, A.B., 1994. Old policies and new competencies, in Duff, A., Pinder, J. and Pryce R. (eds.) Maastricht and beyond: building the European Union. London, Routledge, 123-139.

Puppim de Oliveira, J.A.P., 2009. The implementation of climate change related policies at the subnational level: An analysis of three countries. Habitat International, 33 (3), 253-259.

Quinn, B., 2003. Irish local government in a comparative context, in Callanan, M. and Keogan, J.F. (eds.) Local government in Ireland: inside out. Dublin, Institute of Public Administration, 447-459.

Shackley, S. and Deanwood, R., 2002. Stakeholder perceptions of climate change impacts at the regional scale: implications for the effectiveness of regional and local responses. Journal of Environmental Planning and Management, 45 (3), 381-402.

Sovacool, B.K. and Brown, M.A., 2009. Scaling the policy response to climate change. Policy and Society, 27 (4), 317-328.

Tipperary Energy Agency, 2007. Climate Change Strategy for the Mid West Region. Cahir, Co. Tipperary, Tipperary Energy Agency.

Tribbia, J. and Moser, S.C., 2008. More than information: what coastal managers need to plan for climate change. Environmental Science \& Policy, 11 (4), 315-318.

Urwin, K. and Jordan, A., 2008. Does public policy support or undermine climate change adaptation? Exploring policy interplay across different scales of governance. Global Environmental Change, 18 (1), 180-191. 
Waterford County Council, 2008. Climate Change Strategy 2008-2012. Dungarvin, Waterford County Council.

Wilbanks, T.J., 2007. Scale and sustainability. Climate Policy, 7 (4), 278-287.

Wilson, E., 2006. Adapting to climate change at the local level the spatial planning response. Local Environment, 11 (6), 609-625. 